\title{
S. P. Huntington's Civilizations Twenty-Five Years On
}

Jan Slavíček

The study is based on the concept of Huntington's civilizations. They were used as a methodological basis for an analysis of the changes in their geopolitical power between 1995-2020 with the following conclusions: I) The large population growth of $1995-2020$ has been driven primarily by African, Islamic and Hindu civilizations, 2) Economically, the unquestionable superiority of Western civilization has remained, although its share has declined. A large economic growth has been mainly seen in the Confucian and Hindu civilizations, 3) Of the core countries, the USA, Russia, and China match the status of superpowers, while for India it seems to be only a matter of time, 4) Most of the civilizations are economically highly compact and their compactness has increased over the last 25 years (except of African civilization) and 5) The Western, Hindu and Latin-American civilizations are politically highly compact. Conversely, the African, Islamic, Orthodox and Confucian civilizations show low cohesion. The Muslim civilization is the least compact - politically as well as economically. 6 . The superpowers (United States, China, Russia and India) will remain or become the most important players in the multipolar world of the $2 \mathrm{I}^{\text {st }}$ century. However, it is a question whether the most important issue will be the relations of the Western and non-Western world or the mutual relations among the other three (actual or rising) superpowers.

Jan Slavíček. S. P. Huntington's Civilizations Twenty-Five Years On. Central European Journal of International and Security Studies I4, no. 2: 53-85.

(C) 2020 CEJISS. Article is distributed under Open Access licence: Attribution NonCommercial 3.o Unported (cc by-nc 3.0). 
Keywords: S. P. Huntington, S. B. Cohen, geopolitics, civilizations, I9952020, economics, compactness, clash of civilizations, military power, international relations.

CEJISS In 20I8, 25 years have passed from the moment when Samuel P. Hun2/2020 tington published his famous article in Foreign Affairs ${ }^{I}$. His study has aroused the greatest debates and has become the most frequently cited since the publication of the "long telegram's at the very beginning of the Cold War. Huntington elaborated his opinions in his still more famous monograph The Clash of Civilizations. ${ }^{3}$ In this book he presented his relatively compact theory of the division of the world after the end of the Cold War.

Samuel P. Huntington divided the world into altogether 9 civilizations in his work. ${ }^{4}$ Their core (i.e. what primarily connects and defines them) were religions. These civilizations were: Western, Slavic-Orthodox, Confucian $\left(=\right.$ Sinic $=$ Chinese), Hindu, Buddhist ${ }^{5}$, African, Islamic (= Muslim), Latin-American and Japanese. With the last two mentioned, Huntington admitted a certain confusion. Latin America has the same religion as Western civilization and its countries have been relatively close to it even in terms of values. Despite that, Huntington distinguished it as a specific civilization. Furthermore, Japanese civilization comprises only one country. It could therefore also be a 'lone state', thus a country not belonging to any civilization ${ }^{6}$, but considering its economic importance Huntington took it as an independent civilization ${ }^{7}$. The author has decided to respect these conclusions by Huntington and has proceeded in accord with them.

Huntington's concept has become the target of strong criticism. Most critics addressed his paradigm of civilizational conflicts as a growing problem of international relations in the $2 \mathrm{I}^{\text {st }}$ century. ${ }^{8}$ However, civilizational conflicts are not the focus of this paper. On the other hand, regarding to this study the following three objections are important: I) Huntington's theory is not accurate, it is simplifying and generalizing, for example the boundaries between civilizations cannot be defined that rigid; 2) It disregards such phenomena as interdependency in international relations or cultural exchange; 3) Most importantly, the cohesion of particular civilizations is very low and a lot of countries have often better relations with states from another civilization than with members of their own. For example, Saudi Arabia is hostile to Iran while it is the ally of the USA. The relations between 
China and several members of Confucian civilization are quite poor as well (Taiwan, Vietnam). The same can be stated about Russia and its several neighbors, to mention only three examples. What is even more important, the cohesion of several civilizations has not strengthened in the last decades - on the contrary, it has weakened to such an extent that it starts calling Huntington's whole theory into question. ${ }^{9}$ All three points are correct, at least partially. Regarding the first one, Huntington himself admitted that being a model, his theory is (and must be) simplifying ${ }^{\text {Io }}$. Second, interdependency and cultural exchange are closely related to globalization, which is one of his important points. Globalization can bring the people (and nations) 'closer' to each other. On the other hand, it can also strengthen the perception of distinctions and differences. The third argument is probably the most valid and must be considered seriously - Huntington's division can be accepted as a basis for a quantitative analysis of geopolitical power despite the fact that this division is not exact. Furthermore, the last part of the article analyzes a part of this problem (the compactness of Huntington's civilizations).

Besides all the mentioned objections, it is clearly visible that Huntington's concept is not purely geopolitical. Its world's division is based on religions and cultures, while geopolitics is based on geography. The 'classical' recent work of the latter is Geopolitics by Saul Bernard Cohen ${ }^{\text {II }}$. In this book, the world after the end of the Cold War is divided into three geostrategic realms: the maritime realm, the Eurasian continental realm and the East Asia realm. Each of them includes several geopolitical regions. They are North and Central America, South America, maritime Europe and the Maghreb, and the Asia-Pacific Rim for the maritime realm; heartlandic Russia, Central Asia and the Trans-Caucasus for the continental realm; and mainland China and Indochina for the East Asia realm. Besides these, an independent South Asia region exists. Under the leadership of India, it can evolve into the fourth realm in the future. The Cohen's division of world involves also two shatterbelts (regions with great internal instability, which is furthermore multiplied by imperial politics of the great powers) - The Middle East and Sub-Saharan Africa. ${ }^{12}$

Nevertheless, regarding the division of the world, if we compare Huntington's and Cohen's books, there are significant resemblances between these two theories. The biggest difference is that in Cohen's division, the Islamic civilization of Huntington is split into sever- 
al regions: The Asia Pacific Rim (esp. Indonesia), the maritime Europe and the Maghreb, and the Middle East and Sub-Saharan Africa shatterbelts. The Buddhist civilization is a part of East-Asia realm (without Mongolia) and Japan belongs to the Asia-Pacific Rim. While Hun-

CEJISS tington's division of American continent is North America vs. Central 2/2020 and South America, in Cohen's book Central America is a part of the North American region. Besides that, the other boundaries are approximately the same: The Maritime realm corresponds to the Western, Latin-American and Japanese civilizations, and the Eurasian continental realm to the Orthodox civilization. The East-Asia realm is roughly the same as the Sinic civilization of Huntington, while the South Asia region matches the Hindu and the Sub-Saharan Africa shatterbelt corresponds to the African civilization. ${ }^{13}$

I am fully aware of the mentioned flaws of the Clash of Civilizations. On the other hand, I simultaneously believe, there are still useful lessons that can be taken from Huntington's work - his critics do believe this as well. ${ }^{14}$ However, the aim of this article is not an analysis of Huntington's theory itself. In the same way, the article does not intend to further develop Huntington's theory. I have adopted his division of the world and, based on that, I have conducted my own statistical analysis and quantitative research based particularly on the official data of various databases, such as those of International Monetary Fund (IMF), Military Balance, Globalfirepower (GFP), SIPRI or Uppsala University.

The article analyzes the transformations undergone by the geopolitical power of the individual civilizations defined by Huntington in $1995-202 \mathrm{O}^{15}$. The analysis focuses on a comparison of the basic indicators of geopolitical power. In the first part, it deals with the populations and economy $\left(\mathrm{GDP}^{\mathrm{I}}\right)$ of the individual civilizations, as well as their shares of the global numbers. The military factors on the level of civilizations have not been dealt with, because the estimates of military power of a number of countries are difficult to obtain (in some cases practically inaccessible), hard to verify and created by different methodologies.

The second part of the article is devoted to the geopolitical power of the 'core' or 'leading' countries of the individual civilizations. Their area in combination with the population, performance of the economy (GDPn and GDPp) and military force is analyzed here. The deductions have been driven from various statistics publicly accessible databases. ${ }^{17}$ The focus is primarily on I) conventional military power, 2) the num- 
ber of nuclear warheads and 3) Global Firepower Index. Based on this data, the countries are then categorized into first order states (superpower), second order states (power) or third order states (regional power) according to key criteria that have been arbitrarily set in advance. ${ }^{18}$

The last part of the article focuses on the compactness of the individual civilizations, both economic (the differences between the richest and poorest countries) and political (the relations between the countries within the civilizations).

The fundamental questions which the study has broached are: What have been the main geopolitical developmental trends of Huntington's civilizations over the last 25 years? Which civilizations have strengthened, and which have visibly weakened - and what have been the reasons for these changes? Although simplified, it has been possible to capture at least some developmental trends of world geopolitics using Huntington's model as a basis.

\section{Definition of the civilizations}

Huntington operates with several crucial categories of countries. Primarily, it is the core or leading state which is the most important country, or the leader (hegemon) of the given civilization. For some civilizations, it is indisputable (for example, India in the case of Hindu civilization); with others, there are more aspirants (in Western civilization, the USA, and possibly the EU if we took it as a whole). Finally, for some civilizations, there is no leading country (for example, in Buddhist civilization). ${ }^{19}$

Another term used is 'cleft country'. It is a state through whose territory a border of two or more civilizations runs and various parts of the population fall to diverse civilizations. In the past, it was a state such as Yugoslavia (Western, Orthodox and Muslim civilizations), today, for instance Ukraine (its western and central parts belong to Western civilization, while its east to the Orthodox). These states have tended to have a fundamental problem with internal stability and Huntington anticipated their huge problems or even collapse in the future ${ }^{20}-$ and for example the developments in Sudan have proved him essentially correct.

The last term is a 'torn country'. This country belongs historically and culturally to one civilization, but its elites have tried to change this in the long term and to become a member of another civilization. Turkey or Mexico have been presented as examples, which have tried 
to become parts of Western civilization. According to Huntington, a change of civilization membership is practically impossible and condemned to failure. ${ }^{21}$

The precondition for analyzing the geopolitical power of civilizaCEJISS tions is their enumeration. However, in many cases, it is quite compli$2 / 2020$ cated to categorize individual countries in a civilization. In principle, I have respected the original concept of Samuel Huntington, although the boundaries between civilizations have shifted to a certain extent (this is mainly related to shifting the borders of the Islamic civilization in Africa further to the south). For example, Suriname and Guyana are considered cleft countries split between the African and Hindu civilizations, even though they have a significant Muslim population and are also members of the Organization of Islamic Cooperation. Perhaps the only change from the original Huntington concept is the inclusion of Israel into Western civilization.

In 20I9, the UNO had 193 member countries, 2 countries with observer status (the Vatican and Palestine), several dozen dependent territories and several states whose sovereignty is to a greater or lesser degree in question. The well-known cases are Taiwan, Northern Cyprus, Western Sahara, Kosovo, or the separatist regions of the neighbors of the Russian Federation. In terms of methodology, the study counts countries that are members of the IMF or send data to the organization (namely, Taiwan, Puerto Rico, Kosovo and autonomous regions of the PRC - Macao and Hong Kong). On the contrary, the dependent territories, as well as some European microstates (Andorra, Lichtenstein, Monaco) and further the Vatican and Palestine have not been included into the individual civilizations. North Korea and Cuba have been omitted as well. ${ }^{22}$

The presented data cannot be taken with absolute precision, the actual situation can differ in terms of details. On the other hand, they can show relatively precisely the overall power of the individual civilizations (as defined by Samuel Huntington), particularly in the comparative perspective. The world civilizations were divided in this way:

I. African: 33 countries, predominantly of Sub-Saharan Africa, some adjacent island states, as well as two South American states (Guyana and Suriname). Some countries have been placed in the category of 'cleft'.23

2. Buddhist: 7 countries of East Asia. ${ }^{24}$

3. Hindu: 4 countries, of which two (in South America) are cleft. ${ }^{25}$ 
4. Japanese: the only civilization comprised of a lone country, namely Japan.

5. Sinic (Confucian): 6 countries in East Asia (of which one is cleft) and 2 autonomous regions as well. ${ }^{26}$

6. Latin-American: 22 countries from both American continents, Jan Slavíček of which one is cleft. ${ }^{27}$

7. Islamic: 52 states, predominantly from North Africa, the Near/ Middle East and Southeast Asia. Some countries are cleft. ${ }^{28}$

8. Orthodox: 15 countries of the Eurasia, including two cleft countries. ${ }^{29}$

9. Western: 43 countries mainly from the Euro-Atlantic and Pacific areas. Three of these countries were classified as cleft..$^{\circ}$

Apart from the above-mentioned civilizations, there is a number of 'lone'states and countries that are difficult to classify. ${ }^{3}$

\section{Development of the population and economic power of civilizations in 1995-2020 ${ }^{32}$}

To compare the transformations of the geopolitical power of the individual civilizations over the last 25 years, the article analyses their shares in the world economy and population. An overview of the development of the population is provided in the following table I.

Table I. Populations of the individual civilizations (in mil. of people and percentual change) between 1995 and $2020^{33}$

\begin{tabular}{|c|c|c|c|c|}
\hline Civilization & \multicolumn{2}{|c|}{ Year } & \multicolumn{2}{c|}{ Change 1995 $\rightarrow \mathbf{2 0 2 0}$} \\
\hline & $\mathbf{1 9 9 5}$ & $\mathbf{2 0 2 0}$ & abs. & $\mathbf{\%}$ \\
\hline AFR & 343,23 & 685,40 & $+342, \mathrm{I} 7$ & $+99,69 \%$ \\
\hline BDH & 95,42 & $\mathrm{I} 7 \mathrm{I}, 5 \mathrm{O}$ & $+76,09$ & $+79,74 \%$ \\
\hline CNF & $\mathrm{I} 357,73$ & $\mathrm{I} 587,77$ & $+230,04$ & $+\mathrm{I} 6,94 \%$ \\
\hline HIN & 958,98 & $\mathrm{I} 400,55$ & $+44 \mathrm{I}, 57$ & $+46,05 \%$ \\
\hline ISL & $\mathrm{I}$ 0I $4, \mathrm{I} 2$ & $\mathrm{I} 680,78$ & $+666,67$ & $+65,74 \%$ \\
\hline JAP & $\mathrm{I} 25,44$ & $\mathrm{I} 25,75$ & $+\mathrm{O}, 3 \mathrm{I}$ & $+\mathrm{O}, 25 \%$ \\
\hline LAT & 455,33 & $6 \mathrm{I} 6,45$ & $+\mathrm{I} 6 \mathrm{I}, \mathrm{II}$ & $+35,38 \%$ \\
\hline ORT & $255,6 \mathrm{I}$ & 252,57 & $-3,03$ & $-\mathrm{I}, \mathrm{I} 9 \%$ \\
\hline WST & $84 \mathrm{I}, 49$ & 989,36 & $+\mathrm{I} 47,87$ & $+\mathrm{I} 7,57 \%$ \\
\hline World & $\mathbf{5 7 5 1 , 4 7}$ & $\mathbf{7 7 9 5 , 4 8}$ & $\mathbf{+ 2} \mathbf{0 4 4 , 0 1}$ & $\mathbf{+ 3 5 , 5 4 \%}$ \\
\hline
\end{tabular}

Source: International Monetary Fund (2019); United Nations (2017) 'World Population Prospects: The 2017 Revision. United Nations, Population Division, Department of Economic and Social Affairs,' <https://population.un.org/wpp/Download/Standard/ Population/> (accessed on I2 August 2018) 
A quick glance at the table reveals fundamental differences in the relative speed of population increase. The overall growth of the world population in $1995-2020$ is estimated at more than two billion people, thus by more than a third. However, it is very unevenly distributed CEJISS among the individual civilizations. Among those growing faster than $2 / 2020$ the average are the Hindu but especially the Islamic (with a growth of almost 66 percent) and the Buddhist civilizations (almost 8o percent of growth). African civilization then completely stands out where an almost doubling of the population is expected over only a 25 -year period of time. ${ }^{34}$ The growth of the population of Latin America is expected to be equally as quick as of the world. The rest of the world, on the contrary, should grow more slowly and its share in the world population should thus decline. This is the case of the Western and Confucian civilization, the population growth of which is anticipated to slow very rapidly. Actual stagnation is evident with Japanese civilization and a decline of the population has affected the Orthodox civilization. 35 The trends described above are confirmed also by Table 2 . It indicates a relatively rapid decline of the shares of the Confucian, Japanese, Orthodox and Western civilizations. The share of the Latin American civilization remains relatively stable. On the contrary, the shares of the African and Islamic civilizations have risen swiftly, and the Hindu and Buddhist civilizations more slowly (by the Buddhist civilization the reason is its marginal share of world population despite its rapid growth).

Table 2. Development of the shares of the civilizations in the world population in 1995-2020

\begin{tabular}{|c|c|c|c|c|c|c|c|c|c|c|}
\hline Year & Share & 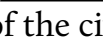 & int & th & rld & Iatt & (1) & ge) & & \\
\hline & AFR & $\mathrm{BDH}$ & CNF & $\mathrm{HIN}$ & ISL & JAP & LAT & ORT & WST & TOT \\
\hline I995 & $5,97 \%$ & $\mathrm{I}, 66 \%$ & $23,61 \%$ & $16,67 \%$ & $17,63 \%$ & $2,18 \%$ & $7,92 \%$ & $4,44 \%$ & $14,63 \%$ & $94,71 \%$ \\
\hline 2000 & $6,39 \%$ & $2,40 \%$ & $23,16 \%$ & $\mathrm{I} 7, \mathrm{I} 5 \%$ & I8,24\% & $2,06 \%$ & $8,03 \%$ & $4,24 \%$ & $\mathrm{I} 4, \mathrm{I} 5 \%$ & $95,83 \%$ \\
\hline 2005 & $6,94 \%$ & $2,35 \%$ & $22,48 \%$ & $17,46 \%$ & I9,67\% & $\mathrm{I}, 95 \%$ & $8,05 \%$ & $3,90 \%$ & $13,76 \%$ & $96,57 \%$ \\
\hline 2010 & $7,45 \%$ & $2,30 \%$ & $2 \mathrm{I}, 7 \mathrm{I} \%$ & $17,65 \%$ & $20,43 \%$ & $\mathrm{I}, 83 \%$ & $8,05 \%$ & $3,65 \%$ & $\mathrm{I} 3,40 \%$ & $96,47 \%$ \\
\hline 2015 & $8,15 \%$ & $2,25 \%$ & $21,02 \%$ & $\mathrm{I} 7,77 \%$ & $20,83 \%$ & $\mathrm{I}, 72 \%$ & $8,01 \%$ & $3,43 \%$ & $\mathrm{I3}, \mathrm{OI} \%$ & $96,18 \%$ \\
\hline 2020 & $8,79 \%$ & $2,20 \%$ & $20,37 \%$ & $\mathrm{I} 7,97 \%$ & $2 \mathrm{I}, 56 \%$ & $\mathrm{I}, 6 \mathrm{I} \%$ & 7,91\% & $3,24 \%$ & $12,69 \%$ & $96,34 \%$ \\
\hline
\end{tabular}

Source: International Monetary Fund (20I9); United Nations (20I7)

The comparison of changes in the nominal gross domestic product of individual civilizations is different from that of the population (Table 3 below). In the quarter century between 1995 and 2020, the share 
of Western civilization in global GDPn has declined by ten percent. However, its position as the leader of the global economy remains indisputable and it is expected to generate still more than half of the world's economic production in 2020. Japan's share has fallen sharply (from approximately I7.5 percent in 1995 to ca 6 percent in 2020). ${ }^{36} \mathrm{On}$ the other hand, Confucian civilization has experienced rapid growth S. P. Huntington's Civilizations (from not quite 6 percent in 1995 to more than 20 percent estimated for 2020). The share of the Hindu civilization has grown quite rapidly, but it must be taken into account that growth started from a very low base, and that the share of global GDPn is also estimated to be relatively low for 2020 (roughly 3.5 percent). The other civilizations have grown more slowly or their share has stagnated (Latin American civilization).

Table 3. Development of the shares of the civilizations in global GDPn in $1995-2020$

\begin{tabular}{|c|c|c|c|c|c|c|c|c|c|c|}
\hline Year & \multicolumn{10}{|c|}{ Share of the civilization in the global GDPn (percentage) } \\
\hline & AFR & $\mathrm{BDH}$ & CNF & $\mathrm{HIN}$ & ISL & JAP & LAT & ORT & & OT \\
\hline 1995 & $\mathrm{I}, \mathrm{I} 3 \%$ & $0,62 \%$ & $75 \%$ & $\mathrm{I}, 20 \%$ & $4,97 \%$ & $\mathrm{I} 7,58 \%$ & $6,10 \%$ & $\mathrm{I}, 89 \%$ & & \\
\hline 2000 & $0,92 \%$ & $0,48 \%$ & $6,97 \%$ & $\mathrm{I}, 43 \%$ & $5,86 \%$ & $\mathrm{I} 4,44 \%$ & $6,50 \%$ & $\mathrm{I}, 60 \%$ & & \\
\hline 2005 & $\mathrm{I}, 22 \%$ & $0,51 \%$ & $8,20 \%$ & $\mathrm{I}, 78 \%$ & $6, \mathrm{II} \%$ & $10,00 \%$ & $5,69 \%$ & $2,95 \%$ & $63,41 \%$ & $99,87 \%$ \\
\hline 2010 & $\mathrm{I}, 49 \%$ & $0,70 \%$ & $\mathrm{I} 2,26 \%$ & $2,62 \%$ & $8,10 \%$ & $8,63 \%$ & $7,65 \%$ & $3,85 \%$ & $54,55 \%$ & $99,84 \%$ \\
\hline 2015 & $\mathrm{I}, 48 \%$ & $0,79 \%$ & $\mathrm{I} 8,52 \%$ & $2,85 \%$ & $8,31 \%$ & $5,88 \%$ & $7,02 \%$ & $2,93 \%$ & $52,04 \%$ & $99,82 \%$ \\
\hline 2020 & $\mathrm{I}, 4 \mathrm{I} \%$ & $0,84 \%$ & $20,35 \%$ & $3,57 \%$ & $7,83 \%$ & $5,95 \%$ & $6,02 \%$ & $2,93 \%$ & $50,57 \%$ & $99,48 \%$ \\
\hline
\end{tabular}

Source: International Monetary Fund (2019)

The comparison of the nominal GDP of the individual civilizations turns out relatively clear-cut. However, if we compare the GDPp (Table 4 below), we obtain a rather different picture. First, this parameter allows us to identify the advanced civilizations - i.e. those in which the GDPp is only a little higher or similar (Confucian and Latin American civilizations) or even lower than the GDPn (Western but mainly the Japanese civilization). Their counterparts are poorer civilizations, essentially made up of developing countries. In those, GDPp is substantially higher than GDPn (Buddhist, Orthodox, African, but predominantly Islamic and Hindu civilizations). In other words - the actual economic productivity of these civilizations is higher than it would seem based on the nominal calculation.

Second, the overall development trends of some civilizations differ considerably when both parameters are used. Confucian, Islamic, 
and Hindu civilizations have been growing more slowly than the GDPn-based method suggested but the decline of the share of Japanese civilization is also slower (simultaneously, its weight in the world is also significantly lower than by GDPn). On the contrary, the reduction CEJISS of the share of the Western civilization seems to be faster. The devel2/2020 opment of the Latin American and Orthodox civilizations is interesting. With the nominal parameter they have either stagnated (the first mentioned) or grown slowly (the latter mentioned). When the recalculation to purchasing power parity is used, both have recorded a drop of their share; this trend is even more obvious in the Latin American civilization.

Table 4. Development of the shares of the civilizations in global GDPp in I995-2020

\begin{tabular}{|c|c|c|c|c|c|c|c|c|c|c|}
\hline Year & Jital & & & & Jat & & & & & \\
\hline & AFR & $\mathrm{DH}$ & CNF & HIN & ISL & JAP & LAT & & & TOT \\
\hline I995 & $\mathrm{I}, 83 \%$ & $\mathrm{I}, 28 \%$ & $9,01 \%$ & $3,80 \%$ & $\mathrm{I} 2,77 \%$ & $7,77 \%$ & $9,56 \%$ & $5,40 \%$ & $48,38 \%$ & \\
\hline 2000 & $\mathrm{I}, 85 \%$ & $\mathrm{I}, 25 \%$ & I0,77\% & $4,23 \%$ & $\mathrm{I} 2,70 \%$ & $6,82 \%$ & $9,17 \%$ & & & \\
\hline 2005 & $\mathrm{I}, 97 \%$ & $\mathrm{I}, 39 \%$ & $\mathrm{I} 3,30 \%$ & $4,84 \%$ & $13,67 \%$ & $5,98 \%$ & $8,60 \%$ & $5,54 \%$ & $44,48 \%$ & $99,77 \%$ \\
\hline 2010 & $2,13 \%$ & $\mathrm{I}, 47 \%$ & $17,57 \%$ & $6,00 \%$ & $14,36 \%$ & $5,02 \%$ & $8,62 \%$ & $5,46 \%$ & $39,13 \%$ & $99,75 \%$ \\
\hline 2015 & $2,23 \%$ & $\mathrm{I}, 53 \%$ & $20,74 \%$ & $7,01 \%$ & $\mathrm{I} 4,66 \%$ & $4,44 \%$ & $8,15 \%$ & $4,96 \%$ & $36,01 \%$ & $99,72 \%$ \\
\hline 2020 & $2, \mathrm{II} \%$ & $\mathrm{I}, 59 \%$ & $23,36 \%$ & $8,45 \%$ & $\mathrm{I} 4,7 \mathrm{I} \%$ & $3,93 \%$ & $7,04 \%$ & $4,63 \%$ & $33,73 \%$ & $99,56 \%$ \\
\hline
\end{tabular}

Source: International Monetary Fund (2019)

To sum up the development of the shares of the individual civilizations on the global economy in 1995-2020: First, the shares of Western and Japanese civilizations have been declining at a relatively fast pace. Second, a sharp increase in the share has been achieved in the Confucian civilization category (primarily but not only thanks to the spectacular economic development of the PRC). Third, the African, Buddhist, Latin American and Orthodox civilizations are among those stagnating or only gradually increasing their share. Fourth, the Islamic and Hindu civilizations'shares have grown somewhat more quickly but it is necessary to take into account that they started from a relatively low base. However, particularly in the case of the Hindu civilization, a lot of economists agree, that it has signs of becoming the economic leader (or co-leader) of the world in the future. ${ }^{37}$

The trends indicated above are also essentially confirmed by Table 5. It shows the changes of the GDP of the individual civilizations between 1995 and 2020. Whereas the GDPn of the entire world has 
Table 5. GDPn and GDPp of the individual civilization civilizations I995-2020

\begin{tabular}{|c|c|c|c|c|c|c|c|c|}
\hline \multirow[t]{3}{*}{ Civilization } & \multicolumn{4}{|c|}{ GDPn (USD bn.) } & \multicolumn{4}{|c|}{ GDPp (CID bn.) } \\
\hline & \multicolumn{2}{|l|}{ Year } & \multicolumn{2}{|c|}{ Change $1995 \rightarrow 2020$} & \multicolumn{2}{|l|}{ Year } & \multicolumn{2}{|c|}{ Change $1995 \rightarrow 2020$} \\
\hline & I995 & 2020 & abs. & percent & 1995 & 2020 & abs. & percent \\
\hline AFR & 350 & I 301 & $+95 \mathrm{I}$ & $+271,29 \%$ & 702 & 3169 & +2467 & $+35 \mathrm{I}, \mathrm{I} 4 \%$ \\
\hline $\mathrm{BDH}$ & I93 & 778 & +585 & $+303,26 \%$ & 490 & 2389 & +I 899 & $+387,78 \%$ \\
\hline CNF & I 782 & I8 789 & $+\mathrm{I} 7007$ & $+954,56 \%$ & 3455 & 35077 & +31622 & $+915,27 \%$ \\
\hline HIN & 372 & 3295 & +2923 & $+785, \mathrm{IO} \%$ & I 456 & I2 695 & +II 239 & $+77 \mathrm{I}, 67 \%$ \\
\hline ISL & I 540 & 7227 & +5687 & $+369,38 \%$ & 4896 & 22086 & +17 I90 & $+351,12 \%$ \\
\hline JAP & 5449 & 5495 & +46 & $+0,85 \%$ & 2979 & 5896 & $+29 \mathrm{I} 7$ & $+97,91 \%$ \\
\hline LAT & I $89 \mathrm{I}$ & 5559 & +3668 & $+193,99 \%$ & 3666 & IO 579 & $+69 \mathrm{I} 3$ & $+\mathrm{I} 88,58 \%$ \\
\hline ORT & 587 & 2706 & $+2 \mathrm{I} 20$ & $+361,28 \%$ & $207 \mathrm{I}$ & 6959 & +4887 & $+235,95 \%$ \\
\hline WST & I8 807 & 46682 & +27875 & $+\mathrm{I} 48,22 \%$ & I8 550 & 50657 & +32107 & $+173,09 \%$ \\
\hline World & 31003 & 92310 & +61307 & $+\mathrm{I} 97,74 \%$ & 38343 & I50 I69 & +III 826 & $+291,64 \%$ \\
\hline
\end{tabular}

Source: International Monetary Fund (2019)

approximately tripled, there are clear and profound differences among the individual civilizations. Hindu (+ 785 percent) and Confucian (+ 955 percent) civilizations have experienced an enormous boom. African, Buddhist, Islamic and Orthodox civilizations have grown rather more slowly, yet significantly faster than the world as a whole. The growth of the Latin American civilization (+ I94 percent) has been average. Overall, 6 of Huntington's 9 civilizations have grown economically faster than the world average. On the other hand, this has been compensated by the slower growth of Western civilization (+ I48 percent) and, above all, the fall of the Japanese economy (according to the estimates, its nominal GDP in 2020 should be only I percent higher than in I995!).

A more plastic image is rendered when GDPp is used. First of all, world economic growth has been noticeably faster $(+292$ percent vs. + I98 percent). It confirms the strong lead in the development of the Confucian and Hindu civilizations (+ 9I5 percent and +772 percent). Then there is a group of civilizations that remain above the world average, but their growth rate has been approximately $2-3$ times slower than the previous two. They are the African (+ 35I percent), Buddhist $(+388$ percent) and Islamic (+ 35I percent) civilizations. The Orthodox (+ 236 percent), Latin American (+ I89 percent) and Western (+ I73 percent) civilizations have achieved lower-than-average GDP growth 
rates. The slowest development has been experienced by Japanese civilization (+ 98 percent). However, there is not a decline as with nominal GDP.

\section{CEJISS Geopolitical power of core countries}

2/2020 As was already mentioned, an important principle of Huntington's division of the world is the concept of so-called leading or core countries. This country is a hegemon of the civilization, i.e. the other member-states are to a greater or lesser degree dependent on it, or must in essence take into account its interests. The concept of leading states became Huntington's groundwork on a proposal for a reform of the UN Security Council..$^{8}$ From the point of view of geopolitical power, the following civilizations have a clear hegemon: Japanese (Japan, of course, could be seen as a 'lone country' as stated above), Confucian (People's Republic of China), Hindu (India) and Orthodox (Russian Federation). The situation is rather more complicated in the remaining five civilizations. In the case of Western civilization, the undoubtable hegemon in terms of military strength is the Unites States of America, but in terms of economics it shares this position with the EU (considering the EU as a geopolitical whole as Huntington himself did). For the purposes of this study, only the US is counted as the hegemon of Western civilization.

The problem of the concept of a leading state arises clearly with the remaining four civilizations. In the case of Buddhist civilization, all of the countries are geopolitically relatively weak and thus they do not meet the criteria to play the role of a hegemon. I have decided, within a simplification, to designate the country with the most economic strength as the leading country of this civilization - Thailand. ${ }^{39}$

In the three remaining civilizations, there is a problem of determining a hegemon at all. Therefore, more countries from each civilization have been included, because either their position of hegemon is disputed (e.g. Brazil) or they are alternative candidates for this position (e.g. Argentina). In African civilization, two strongest countries have been chosen - South Africa and Nigeria..$^{40}$ In the case of Latin America, Brazil would be the natural candidate, but it is the only Lusophone country of this civilization, which is a significant barrier to its leadership. On the contrary, the two Hispanophone candidates (Mexico and Argentina) are substantially weaker geopolitically and Mexico, according to Huntington, is moreover an example of a torn country. 
This problem is even more intense in the Muslim civilization. Indonesia would be the natural candidate here (the country with the largest population and economy), but it lacks the ambition. In contrast, there are three countries in the Middle East with that ambition - Turkey, Saudi Arabia and Iran. ${ }^{4 \mathrm{I}}$ Their ambitions rely on different bases. Saudi Arabia is the cradle of Islam, one of the wealthiest countries and the world's largest producer of oil. Turkey is one of the most modern and most secularized (and thus closest to the West) countries of the civilization. Iran has a large population and also economic potential. The problem is that the relations among these countries are very tense to hostile in the long term. Saudi Arabia is religiously very conservative and Sunnite, whereas Turkey is modernized and secular and Iran is a Shiite country. Pakistan, which has one of the largest armies of the Muslim civilization and the only one with its own nuclear weapons, also cannot be forgotten when we mention aspirations to lead the civilization.

Some categories must be set out to assess the strength of the individual leading countries. These are the superpower, power and regional power categories, similar to Cohen's first, second and third order states. ${ }^{42}$ The membership of each country in the relevant group has then been judged according to four chosen and measurable criteriat3:

I. Geopolitical position: It is based on the sum of the area ${ }^{44}$ and population expressed by the ratio to the size of the whole world. It starts from the fact that extensive territory and a large population are indispensable for a strong country and they are the base of the other parameters (military might, economy). ${ }^{45}$

2. Economy: It is measured by the share of world GDP (both in nominal and in terms of purchasing power parity). The country must achieve a higher fixed stake in one of these categories and a lower fixed stake in the second category at the same time. ${ }^{46}$

3. Number of nuclear warheads: The ownership of nuclear weapons makes a country in every case important or at least a non-ignorable player in international relations. ${ }^{47}$

4. Conventional military force ${ }^{48}$ : It consists of a combination of military personnel ${ }^{49}$, the number of combat aircraft ${ }^{50}$, armored combat vehicles ${ }^{51}$, naval power ${ }^{52}$ and Global Firepower Index (GFPI).

\section{S. P. Huntington's \\ Civilizations}


Table 6. Parameters for inclusion of the countries in the categories of geopolitical power

\begin{tabular}{|l|l|l|l|}
\hline Indicator & Superpower & Power & Regional power \\
\hline Geopolitical position & $>$ IO $\%$ & $>3.33 \%$ & $\leq 3.33 \%$ \\
\hline Economic productivity & $>\mathrm{I} 5 \%$ and $>5 \%$ & $>5 \%$ and $>\mathrm{I} .67 \%$ & $\leq 5 \%$ and $\leq \mathrm{I} .67 \%$ \\
\hline $\begin{array}{l}\text { Number of nuclear } \\
\text { warheads }\end{array}$ & $>\mathrm{I}, 000$ & $>0$ & 0 \\
\hline $\begin{array}{l}\text { Military personnel } \\
\text { Military aircraft }\end{array}$ & $\begin{array}{l}>\mathrm{I} 2000,000 \\
\text { people }\end{array}$ & $>666$ o00 people & $\leq 666,000$ people \\
\hline $\begin{array}{l}\text { Armoured combat } \\
\text { vehicles }\end{array}$ & $>\mathrm{I} 5,000$ & $>400$ & $\leq 400$ \\
\hline $\begin{array}{l}\text { Aircraft carriers }+ \text { sub- } \\
\text { marines }\end{array}$ & $>2$ & $>0$ & $\leq 5000$ \\
\hline GFPI & $<0, \mathrm{I}$ & $<0,3$ & 0 \\
\hline
\end{tabular}

The core countries (incl. the potential and disputed) are in table 7 . Moreover, all of the world superpowers and powers are included. ${ }^{33}$ The underlined bold italic parameters fulfill the criteria of superpower, the bold italic are the criteria of the power and the bold parameters are close to match the criteria of power (min. 9o percent achieved).

What could be expected subconsciously clearly arises from the table. The superpowers in the combination of area and population are China, India, the Russian Federation and the United States of America. While Australia, Canada, Brazil and Indonesia are among the powers, their chances for a quick move to a higher category are relatively low. Economically, the superpowers are the PRC and the USA. Japan and India can be counted among the powers. Germany is close to 'power'status (but according to decreasing share of Western civilization in the world economy, it is unlikely that Germany would become a power in this parameter). The nuclear superpowers are the USA and Russia, whereas the powers are the remaining countries with nuclear capability: United Kingdom, France, India, Pakistan, PRC, Israel and North Korea. ${ }^{56}$

In conventional weapons, PRC, Russia and the USA have a full superpower status, and India is close to it. India is also the only fully-fledged power, i.e. meeting all the necessary criteria in conventional weapons. The countries close to this position (matching or getting close to four of the five parameters) can also be included into powers - 
Table 7. Geopolitical power of leading countries54 of the individual civilizations in $2015^{55}$

\begin{tabular}{|c|c|c|c|c|c|c|c|c|c|c|}
\hline \multirow[t]{2}{*}{ Country } & \multicolumn{2}{|c|}{$\begin{array}{l}\text { Geopolitical } \\
\text { position }\end{array}$} & \multicolumn{2}{|c|}{ Economy } & \multirow[t]{2}{*}{ NW } & \multicolumn{5}{|c|}{ Conventional military power } \\
\hline & $\begin{array}{l}\text { AR } \\
(\%)\end{array}$ & $\begin{array}{l}\text { POP } \\
(\%)\end{array}$ & $\begin{array}{l}\text { GDPn } \\
(\%)\end{array}$ & $\begin{array}{l}\text { GDPp } \\
(\%)\end{array}$ & & MP & $\mathrm{CA}$ & $\mathrm{ACV}$ & ACS & $\begin{array}{l}\text { GFPI } \\
(2019)\end{array}$ \\
\hline ARG & $\mathrm{I}, 84$ & 0,58 & 0,86 & 0,77 & $\mathrm{O}$ & 106 & 146 & I I35 & $\mathrm{o}$ & 0,6274 \\
\hline AUS & 5,16 & 0,32 & $\mathrm{I}, 65$ & $\mathrm{I}, \mathrm{OO}$ & $\mathrm{O}$ & 80 & I30 & I 743 & $\mathrm{o}$ & 0,3277 \\
\hline BRA & 5,61 & 2,76 & $2,4 \mathrm{I}$ & 2,79 & $\mathrm{o}$ & 2054 & 205 & I 555 & 1 & 0,2487 \\
\hline CAN & 6,11 & 0,48 & 2,08 & $\mathrm{I}, 42$ & $\mathrm{O}$ & IOI & 210 & I 393 & 0 & $0,394 \mathrm{I}$ \\
\hline DPRK & 0,08 & 0,34 & 0,02 & 0,03 & $>0$ & 1979 & 663 & 6560 & o & 0,3274 \\
\hline EGY & 0,67 & $\mathrm{I}, 2 \mathrm{I}$ & 0,44 & 0,93 & $\mathrm{O}$ & 1315 & 504 & 8650 & o & 0,2283 \\
\hline FR & 0,43 & 0,87 & 3,27 & 2,32 & 300 & 346 & 591 & $4 \mathrm{I} 68$ & $\underline{5}$ & 0,1584 \\
\hline GER & 0,23 & I,II & 4,53 & 3,36 & $\mathrm{o}$ & 227 & 388 & 2515 & o & 0,2097 \\
\hline GRC & 0,09 & 0,15 & 0,26 & 0,25 & $\mathrm{O}$ & 366 & 287 & $4 \mathrm{I} 26$ & o & 0,4955 \\
\hline IDN & 1.22 & 3,46 & $\mathrm{I}, \mathrm{I} 5$ & 2,47 & $\mathrm{O}$ & 1077 & 88 & I 282 & o & 0,2804 \\
\hline IND & $\underline{2.00}$ & $\underline{17,38}$ & 2,82 & 6,94 & $\begin{array}{l}100- \\
120\end{array}$ & $\underline{3905}$ & 1598 & 5765 & 2 & 0,1065 \\
\hline IRN & I.O3 & $\mathrm{I}, 08$ & 0,50 & $\mathrm{I}, \mathrm{I} 8$ & $\mathrm{O}$ & 913 & 374 & 2993 & o & 0,2606 \\
\hline ISR & $\mathrm{O}, \mathrm{OI}$ & O,II & 0,40 & 0,25 & 80 & 650 & 724 & 7525 & 0 & 0,2964 \\
\hline ITA & 0,20 & 0,82 & 2,45 & $\mathrm{I}, 90$ & $\mathrm{O}$ & 378 & 429 & I 488 & 2 & 0,2277 \\
\hline JPN & 0.24 & $\mathrm{I}, 72$ & 5,88 & 4,44 & $\mathrm{O}$ & 316 & 640 & I 546 & 2 & 0,1707 \\
\hline MEX & 1.31 & 1,64 & $\mathrm{I}, 57$ & $\mathrm{I}, 97$ & 0 & $4 \mathrm{I} 3$ & 73 & 735 & 0 & 0,5574 \\
\hline NGA & 0,61 & 2,42 & 0,66 & 0,95 & $\mathrm{O}$ & 162 & $3 \mathrm{I}$ & 996 & 0 & 0,7007 \\
\hline PAK & 0.52 & 2,57 & 0,36 & $\mathrm{o}, 8 \mathrm{I}$ & $\begin{array}{l}110- \\
130\end{array}$ & 948 & 596 & 4236 & o & 0,2798 \\
\hline PRC & 6.26 & $\underline{18,62}$ & $\underline{15,03}$ & 17,07 & 260 & $\underline{3503}$ & $\underline{2505}$ & 16569 & $\underline{5}$ & $\underline{0,0673}$ \\
\hline $\begin{array}{l}\text { ROC } \\
\text { (TW) }\end{array}$ & 0,02 & 0,32 & 0,70 & 0,96 & 0 & 1964 & 585 & 2905 & o & 0,3956 \\
\hline ROK & 0,07 & 0,69 & $\mathrm{I}, 85$ & $\mathrm{I}, 6 \mathrm{I}$ & 0 & $\underline{5160}$ & 777 & 6210 & o & 0,1761 \\
\hline RSA & 0.82 & 0,74 & 0,43 & 0,63 & 0 & 77 & 4I & 701 & 0 & 0,5405 \\
\hline RUS & 11.00 & $\underline{1,95}$ & $\mathrm{I}, 83$ & $3,3 \mathrm{I}$ & $\underline{7290}$ & 3260 & 1881 & 51549 & $\underline{13}$ & $\underline{0,0639}$ \\
\hline SAU & 0,82 & 0,42 & 0,88 & $\mathrm{I}, 48$ & $\mathrm{O}$ & 252 & 346 & 5394 & $\mathrm{o}$ & 0,4286 \\
\hline THA & 0,34 & O,9I & 0,54 & 0,97 & $\mathrm{O}$ & 654 & 163 & I 955 & 1 & 0,4302 \\
\hline TUR & 0.52 & $\mathrm{I}, 07$ & $\mathrm{I}, 08$ & $\mathrm{I}, 65$ & 0 & 992 & 462 & 9657 & 0 & 0,2089 \\
\hline UK & $\mathrm{O}, \mathrm{I} 6$ & 0,88 & 3,88 & 2,37 & 215 & 266 & 486 & 3019 & $\underline{4}$ & 0,1797 \\
\hline UKR & 0,39 & 0,58 & $0, \mathrm{I} 2$ & 0,30 & $\mathrm{O}$ & 1122 & 317 & $4 \mathrm{I} 45$ & $\mathrm{o}$ & 0,5082 \\
\hline USA & $\underline{6.14}$ & $\underline{4,35}$ & $\underline{24,39}$ & $\underline{15,74}$ & $\underline{7000}$ & 2302 & $\underline{5476}$ & 52063 & $\underline{25}$ & $\underline{0,0615}$ \\
\hline VNM & $0,2 \mathrm{I}$ & $\mathrm{I}, 24$ & 0,26 & 0,48 & $\mathrm{O}$ & $\underline{5522}$ & I39 & 3615 & $\mathrm{O}$ & 0,3988 \\
\hline
\end{tabular}

Source: International Monetary Fund (20I9); United Nations (20I7); Globalfirepower (20I9), Sipri Yearbook (2016), p. 6Io; ClA (2019); The Military Balance (2015); Worldometers (2019) 
Egypt, Israel, North Korea, South Korea and Turkey (all lacking naval power). Relatively close to this status (failing in two parameters of conventional military power) are Brazil, France, Iran, Italy, Japan, Pakistan and the United Kingdom.

CEIISS If we look at this table differently, only one of the countries sur$2 / 2020$ veyed - the USA - has the status of superpower in all the monitored criteria (geopolitical position, economy, nuclear arsenal, conventional military power). Another two countries fulfill three out of four criteria (China lacks a more extensive nuclear arsenal, Russia economic productivity ${ }^{57}$ ). India met one of the criteria (the sum of the area and population), in one it was close to this boundary (conventional military force) and in the two others it ranked among the powers..$^{58}$ If we include among the superpowers those countries that match at least two of the four criteria and simultaneously match at least one of the remaining criteria on the level of a power, then the PRC, USA and Russia would be superpowers (and India would be very close to). Using the similar pattern to include countries into the group of powers (matching two of the four criteria and at least one of the remaining must be close), then only India belongs there. Pakistan is relatively close to this, assuming it would increase either its conventional military power or its population (i.e. geopolitical position). It seems unlikely that any other country would achieve the status of power soon if we do not anticipate the possibility of obtaining nuclear weapons.

Still another look at table 7 partly corresponds to the conclusions of the former chapter - above all the dominant position of the Western and weak positions of the Buddhist and African civilizations. Of the I7 identified countries matching at least one of the criteria of a power (geopolitical position, economy, nuclear military power, conventional military power $\left.{ }^{59}\right), 6$ belong to the Western civilization - Australia, Canada, UK, France, Israel and USA. Four of them fall into the Islamic (Egypt, Indonesia, Pakistan and Turkey) and three of them into the Confucian civilization (PRC, South Korea and North Korea). In four other civilizations, only one country fulfills at least one of the four criteria to belong among the superpowers or powers (Brazil, India, Japan and Russia). No country from Buddhist of African civilization belongs to powers. Nigeria and Mexico are approaching power classification in the combination of area and population, while Germany is close to that in economy. While the four strongest countries (India, PRC, Russia and USA) belong each to different civilization, among the powers, there 
is a clear dominance of Western world (almost one-third of all those states). Moreover, some of the leaders (or aspirants to that) of particular civilizations do not belong into the category of power even in one parameter (Argentina, Iran, Mexico, Nigeria, Saudi Arabia, South Africa and Thailand) - making the geopolitical inequality even more visible.

\section{Compactness of the civilizations}

The following section of the study analyses the compactness of particular civilizations, i.e. the part of Huntington's work that has become the subject of much criticism. The study uses two criteria to measure this. The first of them are the differences between the wealthiest and poorest countries of the given civilization measured through GDPp per capita. When the difference is smaller, the civilization is more compact in this way. In addition, this criterion can be easily measured. ${ }^{60}$ The differences between extreme values, that could greatly distort the overall picture, should be reduced (at least partially). Therefore, the 20 percent of both the richest and poorest countries of the given civilization $^{61}$ are included and their average GDPp per capita is considered. ${ }^{62}$ The resulting numbers are presented in the following tables. ${ }^{63}$

Table 8. GDPp per capita (ICD) of the wealthiest and poorest countries of the individual civilizations in 1995 and 2020

\begin{tabular}{|c|c|c|c|c|c|c|}
\hline \multirow[b]{2}{*}{ Civilization } & \multicolumn{3}{|l|}{ I995 } & \multicolumn{3}{|l|}{2020} \\
\hline & Wealthy & Poor & Ratio & $\begin{array}{l}\text { Weal- } \\
\text { thy }\end{array}$ & Poor & Ratio \\
\hline African & 6757 & 574 & I: II,8 & I6 I92 & I 157 & I: I4,O \\
\hline Buddhist & 6934 & 796 & I: 8,7 & 2I 6IO & 4985 & I: 4,3 \\
\hline Confucian & 28 oI 8 & I 668 & I: 16,8 & 117763 & I4 883 & I: 7,9 \\
\hline Hindu & 6377 & $98 \mathrm{I}$ & I: 6,5 & I6 054 & 3342 & I: 4,8 \\
\hline Islamic & 39784 & 942 & I: 42,2 & 70228 & 2090 & I: 33,6 \\
\hline $\begin{array}{l}\text { Latin- } \\
\text { American }\end{array}$ & I2 6I4 & $28 \mathrm{I} 8$ & I: 4,5 & 3I IO4 & $695 \mathrm{I}$ & I: 4,5 \\
\hline Orthodox & I5 003 & I 862 & I: 8, I & 35768 & IO OOI & I: 3,6 \\
\hline Western & 30830 & $464 \mathrm{I}$ & I: 6,6 & 71 226 & I3 559 & I: 5,3 \\
\hline
\end{tabular}

Source: International Monetary Fund (2019)

The data in Table 8 reveal the differences between the richest and the poorest countries of individual civilizations. Three essential insights can be pointed out. First, between 1995 and 2020, the economic 
cohesion has dramatically increased in most civilizations, including the Muslim one that is very uneven in terms of property. It is the best visible in the Orthodox civilization, where the ratio between the wealthiest and poorest countries was reduced by more than 50 percent. Con-

CEJISS versely, there is an increase in this ratio with the African civilization, $2 / 2020$ i.e. its economic cohesion has decreased. Second, this form of cohesion is clearly not linked to economic development and overall wealth. It is true that cohesive civilizations are among those rather poorer; on the other hand, the poorest - African - belongs to the least compact. The generally wealthiest and most developed civilization (Western) is highly compact (while generally standing somewhere in the middle of all the civilizations).

Third, there are significant differences among civilizations in this sense. It is possible to divide them into three groups ${ }^{64}$. The first of them comprises civilizations with a relatively high economic compactness (the ratio between the poorest and richest countries is at most $\mathrm{I}: 8$ ), the second with medium compactness (the ratio reaches I : 24), and the last group includes civilizations of low compactness (the ratio is higher than $\mathrm{I}: 24$ ). Membership in these groups is summarized in Table 9. Large changes have occurred in the compactness of civilizations between 1995 and 2020. While in 1995 the most represented group was the one of medium compactness, 25 years later most civilizations have a high economic compactness (75 percent), including the two with the biggest populations. The civilization with the lowest consistency (and the only one in the low compactness group) is clearly the Muslim one in both years. Marked contrasts exist within this civilization. In I995, the ratio was approximately 2,5 as high as that of the second least compact civilization and in 2020 it is still more than 2 times as high. The ratio between the most compact (Latin-American in 1995 and Orthodox in 2020) and the least comTable 9. Economic compactness of the individual civilizations

\begin{tabular}{|l|l|l|}
\hline Compactness & I995 & $\mathbf{2 0 2 0}$ \\
\hline High (to 8:I) & LAT, HIN, WST & $\begin{array}{l}\text { ORT, BDH, LAT, HIN, WST, } \\
\text { CNF }\end{array}$ \\
\hline Medium (to 24:I) & $\begin{array}{l}\text { ORT, BDH, AFR, } \\
\text { CNF }\end{array}$ & AFR \\
\hline Low (over 24:I) & ISL & ISL \\
\hline
\end{tabular}

Source: International Monetary Fund (2019) 
pact (Muslim) civilizations has remained approximately the same (roughly i:9) in both years.

Political compactness is used as the second criterion. This is assessed on the basis of an analysis of relations between members of the individual civilizations. It was not possible to study the foreign policy and diplomatic relations of each country because of the limitations of the space of this paper. It is necessary to proceed to a certain degree of simplification, even with the knowledge that some conclusions may not be quite accurate. Therefore, I have decided to rely on two measurable criteria of mutual relations. These are armed conflicts and official diplomatic relations between individual countries.

In the analysis of conflicts, the study is based on the UCDP/PRIO Armed Conflict Dataset, created in a joint project of Uppsala University and the Oslo Research Institute of Peace Studies. It is the largest publicly available database of armed conflicts, currently covering 1946-2018. ${ }^{65}$ The Uppsala database defines the military conflict in the following way: There are at least 25 battle-related deaths in one calendar year. Depending on the intensity of the combat, it distinguishes between type I with low intensity (25-999 battle-related deaths in one calendar year) and type 2 with high intensity (Iooo and more battle-related deaths in one calendar year). Depending on the type, there are four categories of conflicts:

I. Extra-systemic between the state and a non-governmental group not on its territory.

2. The interstate one, whose participants are both states, respectively their governments.

3. Internal, where the first participant is the state or its government and the other is an internal opposition, without the intervention of other states.

4. Internationalized internal conflict, between the state (possibly with the support of other states) and the internal opposition supported militarily by other states or their governments. ${ }^{66}$

Only the conflicts with at least two countries of one civilization whether as a direct participant or a state that supported one of the parties with armed units - were selected. It means that only interstate (2) or internationalized internal (4) conflicts were selected. The analysis does not include frozen conflicts, in which are less than 25 battle-related deaths a year. In the same way, the list does not include conflicts between countries from different civilizations. (The condition is, that there is at 
least one state from the same civilization on both sides of the conflict). The conflicts that have emerged unambiguously from the outside, and in which states of the same civilization played a marginal role are excluded also. II such conflicts took place in the world in I995-20I8 in a total of 25

CEJISS calendar years (table Io). Three of them were localized in Islamic civiliza-

2/2020 tion (with a total of 7 conflict years), 4 in African civilization (Io calendar

Table Io. Armed conflicts in the individual civilizations in $1995-2018^{67}$

\begin{tabular}{|c|c|c|c|c|c|c|}
\hline CFL & Year & Side A & Side B & Type & INT & CIV \\
\hline CNW & 1995 & Ecuador & Peru & 2 & I & LAT \\
\hline BKC & 1996 & Cameroon & Nigeria & 2 & $\mathrm{I}$ & AFR \\
\hline $1 \mathrm{CW}$ & 1996 & DR Congo (Zaire) & Rwanda, Angola, Uganda & 4 & 2 & AFR \\
\hline $1 \mathrm{CW}$ & I997 & DR Congo (Zaire) & Rwanda, Angola, Uganda & 4 & 2 & AFR \\
\hline $2 \mathrm{CW}$ & 1998 & DR Congo (Zaire) & Rwanda, Angola, Uganda & 4 & 2 & AFR \\
\hline $2 \mathrm{CW}$ & 1999 & DR Congo (Zaire) & Rwanda, Angola, Uganda & 4 & 2 & AFR \\
\hline $2 \mathrm{CW}$ & 2000 & DR Congo (Zaire) & Rwanda, Angola, Uganda & 4 & 2 & AFR \\
\hline $2 \mathrm{CW}$ & 2001 & DR Congo (Zaire) & Rwanda, Angola, Uganda & 4 & $\mathrm{I}$ & AFR \\
\hline cCW & 1997 & Congo & Angola, Chad & 4 & 2 & AFR \\
\hline SLW & I997 & Sierra Leone & Guinea, Nigeria & 4 & $\mathrm{I}$ & ISL \\
\hline SLW & 1998 & Sierra Leone & Guinea, Nigeria & 4 & 2 & ISL \\
\hline DEC & 2008 & Djibouti & Eritrea & 2 & I & ISL \\
\hline RGW & 2008 & Georgia & Russia & 4 & $\mathrm{I}$ & ORT \\
\hline CTD & 2011 & Cambodia & Thailand & 2 & $\mathrm{I}$ & $\mathrm{BDH}$ \\
\hline M23 & 2012 & DR Congo & Rwanda, Uganda & 4 & I & AFR \\
\hline M23 & 2013 & DR Congo & Rwanda, Uganda & 4 & 2 & AFR \\
\hline WDB & 2014 & Ukraine & Russia & 4 & 2 & ORT \\
\hline WDB & 2015 & Ukraine & Russia & 4 & 2 & ORT \\
\hline WDB & 2016 & Ukraine & Russia & 4 & $\mathrm{I}$ & ORT \\
\hline WDB & 2017 & Ukraine & Russia & 4 & I & ORT \\
\hline WDB & 2018 & Ukraine & Russia & 4 & $\mathrm{I}$ & ORT \\
\hline YCW & 2015 & Yemen & Coalition & 4 & 2 & ISL \\
\hline YCW & 2016 & Yemen & Coalition & 4 & 2 & ISL \\
\hline YCW & 2017 & Yemen & Coalition & 4 & 2 & ISL \\
\hline YCW & 2018 & Yemen & Coalition & 4 & 2 & ISL \\
\hline
\end{tabular}

Source: Uppsala Conflict Data Program (2019) 
years), 2 in Orthodox civilization (6 conflict years) and one each for the Latin American and Buddhist civilizations (in both cases I year of battles).

However, the actual absence of conflicts between individual countries of a given civilization does not necessarily reflect the reality of mutual relations. For example, there was no conflict between the two Korean countries according to the database, but their relations are certainly not friendly. As mentioned above, the mutual relationships between countries have been taken into account. Two criteria have been analyzed: I) whether they recognized each other diplomatically and 2) whether there was peace between them or not. Based on these criteria, the compactness of individual civilizations can be distinguished as follows ${ }^{68}$ :

- High compactness meets all the following conditions:

I. among the members of the civilization there was a maximum of one level I conflict in a calendar year per 15 members of the civilization,

2. there was no conflict at level 2,

3. no states were in a state of war and

4. there were no more than I case of mutual diplomatic non-recognition per 15 members of the civilization.

- Medium compactness fulfills all the following conditions:

I. among the members of the civilization there were 2-5 conflicts of level $\mathrm{I}$ in a calendar year per fifteen members of the civilization,

2. among the members of the civilization there was at most one I conflict of level 2 in a calendar year per fifteen members of the civilization,

3. at most two states per fifteen members of the civilization were in a state of war and

4. there were I-3 cases of mutual diplomatic non-recognition per fifteen members of the civilization.

- Low compactness is characterized by civilizations which do not meet at least one of the four conditions for inclusion in high or medium compactness.

Based on the criteria above, Huntington's civilizations can be divided according to political compactness as follows (since only one of the four conditions was sufficient to include in the lower category of political compactness, only the most obvious one has been mentioned): 
- Low political compactness has been typical for the following civilizations: African (33 members, 7 conflict years of intensity 2), Confucian (6 members, both Korean states are formally at war and do not recognize one another diplomatically, as well as the PRC and Taiwan), Islamic (52 members, 5 conflict years of intensity 2) and Orthodox ( 15 members, 2 conflict years of intensity 2).

- The Buddhist civilization had medium political compactness (7 members, one conflict year of intensity I).

- The Hindu, Western, Latin American (22 members, one conflict year of intensity I) and the Japanese civilization have been highly politically compact.

\section{Conclusions}

The world has changed significantly in the 25 years since Huntington's analysis - and it will undoubtedly continue to change. The study dealt with these questions: What is the current distribution of power was in the world after a quarter century? What are the main trends of geopolitical development? It is possible to summarize the following conclusions based on the analysis conducted:

I. In terms of the power of the population, the largest civilizations remain the Confucian, Hindu and Islamic (between I8 percent and 22 percent of the global population), the smallest the Japanese, Buddhist and Orthodox (between I.5 percent and 3.5 percent of the global numbers). There are exceptionally large differences in the dynamics of the change. The African civilization has grown at an enormous pace (more than 340 million -it almost doubled in size, which is clearly unsustainable in the long run). The growth of the Islamic, Buddhist and Hindu civilizations has been slower but still at an above-average speed. The share of these civilizations in the world's population has increased proportionally. The other civilizations have grown at a rate around or below the average and their share in the world's population has therefore declined. Japan's population has stagnated for the last 25 years and the population of the Orthodox civilization has even declined. In Russia (which is a core country), the problem of declining population is moreover multiplied by the inequality of the growth of ethnic Russian and Caucasian Muslim populations.

2. From the perspective of economic productivity measured by nominal GDP, the Western civilization remains clearly domi- 
nant, despite a relatively large reduction (from around 6o percent of the global economy in 1995 to an estimated 50 percent in 2020). The productivity of the economy of the Confucian civilization has increased, which was reflected also in the great increase of its share in the global economy (from 6 percent to more than 20 percent between 1995 and 2020). Similarly, Hindu civilization has experienced rapid growth, but the exceptionally low starting base must be taken into account. On the contrary, the share of the Japanese economy has slumped sharply. If we use the same comparison based on GDP recalculated to purchasing price parity, the growth of the share of the Confucian and Hindu civilizations flattens. The decrease of the share of the Japanese civilization is analogically not so big (that confirms the conclusion that the sharp drop of the Japanese GDPn was to a certain extent created by the fall of the exchange rate of its currency). On the contrary, the development of the GDPp of the Western, Latin American and Orthodox civilizations seem to be much more unfavorable than of the GDPn.

3. One of the crucial parts of Huntington's theory is the role of core countries, i.e. hegemons of civilizations. The core countries do not exist at all in some of them (Islamic, Buddhist, African, Latin American), or there are more candidates (these countries were considered in the study). Logically, there are vast differences in the strength of the core countries. The analysis has confirmed the geopolitical superiority of the USA. It is the only country to meet all the four parameters set by the methodology of this study for the category of superpower (the combination of area and population, economic productivity, the number of nuclear weapons and the conventional military power). However, with the combination of area and population, this position is very tight, and it is possible that the USA would lose it in a few decades (as a consequence of a decline of the share in the world population). Three of these parameters are met by Russia (lacking the necessary economic productivity) and the People's Republic of China (lacking the necessary number of nuclear weapons). Therefore, the chances of China to develop into a full superpower are much higher than those of Russia. India is close to fulfilling two categories (it matches the criterion of combination of population and area and is relatively close to in conventional 
military power). For India, it is also only a matter of time (a few decades) to become an economic superpower and could undoubtedly expand the number of its nuclear weapons relatively quickly. In other words, its struggle to reach the status of a superpower could be successful much more easily and quickly than it might seem initially.

4. From the other core countries (or candidates for this position) only Pakistan is approaching the status of a power. The other countries are only regional powers and it seems unlikely they could achieve the higher level without a nuclear arsenal. While the four superpowers (China, India, Russia, USA) are divided among the same number of civilizations, the distribution of strong regional powers (i.e. matching at least one of the four criteria of a power) is unequal. The Western civilization remains the strongest ( 6 countries incl. the superpower of USA), followed by the Muslim (4 countries, but without any superpower or fullscale power) and Confucian ( 3 countries, including the superpower of PRC). For the four other civilizations, only one country belongs to this group. But in the cases of Orthodox and Hindu, these countries are a superpower and full-scale power - Russia and India. Finally, Buddhist and African civilizations do not have any country in this group. This corresponds to the fact that some of the core countries (or candidates) do not meet the status of the power even in one criterion.

5. The economic compactness of the civilizations was measured by the differences in the GDP per capita. Significant changes have occurred in 25 years between 1995 and 2020. Economic cohesion has increased in 6 of the 9 civilizations. It remained approximately the same in the other two (Latin American and, of course, the Japanese), while only in one case it has decreased (African civilization). The Islamic civilization has been the least compact with enormous differences - I:42,2 in 1995 and I:33,6 in 2020. For comparison - in Western civilization (so often criticized for its large differences in property) these ratios were r:6,6 and I:5,3.

6. Political compactness was measured by the number of armed conflicts (whether interstate or internationalized internal) as well as the existence of peace or a state of war between the members of the individual civilizations and then mutual diplomatic recognition in $1995-2020$. Based on these parameters, the 
Japanese (automatically, because it comprises a single country), Western, Hindu and - somewhat surprisingly - also the Latin American civilizations are highly politically compact. The medium cohesive category comprises Buddhist civilization (in consequence of the armed conflict between Cambodia and Thailand in 20II). Low political compactness is shown by the Confucian and Orthodox civilizations but mainly the Islamic and African (in relation to the number of armed conflicts).

To sum up: The post-Cold War world has changed dramatically in the last quarter of a century. As expected by Huntington, the Western world is slowly losing its economic and military superiority. Presumably, this trend is going to continue, but (again, as Huntington predicted) the West will hold its position for the following decades. On the other hand, the non-Western world is not united or cohesive. The other Huntington civilizations (or Cohen's geopolitical realms or regions) differ greatly from each other. This article highlights the great geopolitical power and potential of Sinic and Hindu civilizations (Cohen's East Asia realm and South Asia region). They can - and probably will, if the development further follows the same pattern - become especially important in international relations, being led by full-scale superpowers. Presumably, Russia will hold its position as the world's second most powerful army (considering its nuclear arsenal). Otherwise, the Orthodox world is going to face numerous demographic and economic challenges, as well as problematic relations between Russia and its neighbors. The predictions of stability for the Muslim and African civilizations (nearly mirroring Cohen's two shatterbelts) seem unlikely because of many conflicts and huge population overcrowding (especially in Africa). The three final civilizations will probably not play particularly important roles and their geopolitical power will be descending (Japanese and Latin-American) or growing only marginally (Buddhist civilization). If the multipolarity (like the 'Concert of Europe' in the $\mathrm{I}^{\text {th }}$ century) is going to fully return to the international relations (in this case, however, as 'Concert of the World'), it will be shaped probably by China, India and Russia, and of course by the Western world (which may or may not continue to form two cores of USA and EU). Simultaneously, the most important issue of international relations may soon be not the relations between Western and non-Western world but the mutual relations of the other three superpowers, as soon as their interests start to clash. 
Jan SlavíčeK is affiliated to The Institute of History of the Czech Academy of Sciences and may be reached at slavicek@hiu.cas.cz.

CEJISS

2/2020 The research was conducted under the Czech Academy of Sciences' 'Programme of Support of Prospective Human Resources - Salary Support of Post-Doctoral Fellows at the Workplaces of the CAS' („Program podpory perspektivních lidských zdrojů - Mzdová podpora postdoktorandů na pracovištích AV ČR').

\section{Endnotes}

I Samuel P. Huntington (I993), 'Clash of Civilizations?', Foreign Affairs; Summer I993, Vol. 72. No. 3. pp. 22-49.

2 George C. Kennan (I947), 'The Sources of Soviet Conduct,' Foreign Affairs; Juillet I947, Vol. 25. No. 4. pp. 566-582.

3 Samuel P. Huntington (I997), The Clash of Civilizations: The struggle of cultures and the transformation of the world, New York: Touchstone.

4 The idea of dividing of the World into culture-based groups is not new. Interestingly, one of the first such theories was formulated in Russia in I870s and I88os by Nikolay Danilevsky, whose division included I3 civilizations. However, its concept could have been inspired by older works from abroad. See Jaroslav Kurfürst (20I8), Př́běh ruské geopolitiky. Jak se ruská myšlenka zmocnila více než šestiny světa [The Story of Russian Geopolitics. How the Russian Idea Overwhelmed more than a Sixth of the World], Praha: Univerzita Karlova, Nakladatelství Karolinum, pp. II5-II6.

5 Buddhist civilization is mentioned only a few times and it remains questionable, whether it is a civilization in Huntington's paradigmatic sense. In this study, I have decided to accept it as a civilization, according to maps in Huntington (1997).

6 Huntington explicitly mentions e.g. Ethiopia or Haiti as such lone countries. Huntington (1997), p. 136.

7 Huntington (1997), pp. 45-48.

8 For an extensive overview of this criticism and for a very conclusive quantitative analysis see Jonathan Fox (2005), 'Paradigm Lost: Huntington's Unfulfilled Clash of Civilizations Prediction into the 2Ist Century, International Politics, Vol. 42, pp. 428-457. His paper rejects (or, at least proves as inconclusive) five Huntington's hypotheses about the growing rate of civilizational conflicts in post-cold-war era, as well as the bigger brutality of conflicts involving the Muslim civilization.

9 Seth Cropsey and Harry Halem (20I8), 'Clash of Civilizations or Clash Within Civilizations?', The American Interest, Vol. I4, No. 2, available at $\quad<$ https://www.the-american-interest.com/2018/o8/3i/clash-ofcivilizations-or-clash-within-civilizations/> (accessed on I8 August 2019).

Io Huntington (I997), pp. I3-I4. 
II Saul Bernard Cohen (2015), Geopolitics: The Geography of International Relations, Third edition, Lanham: Rowman \& Littkefield.

I2 Cohen (2015), p. 44.

I3 Cohen (2015), p. 45; Huntington (I997).

I4 For example, Cropsey and Halem state: „Certain broad insights - in particular, the endurance of value differences between the West and nonWest and how it would shape politics going forward - were accurate. Moreover, several of his discrete predictions, such as, for example, the shifting military balance toward non-Western civilizations and the dynamics of fault-line conflicts, have enjoyed resounding vindication over the past two decades.' Cropsey and Halem (2018).

I5 The year 2020 was selected so that the timeframe of the study takes 25 years since 1995. For 2019 and 2020, qualified International Monetary Fund estimates were available of geopolitical strength in non-military parameters. In some countries, final data for years 2018 and 2017 (or even some years before) were not available yet, therefore the numbers are estimations either. For particular cases see International Monetary Fund (2019) 'World Economic Outlook Database, April 2019,' <https://www.imf. org/external/pubs/ft/weo/20I9/or/weodata/index.aspx> (accessed on 07 July 20I9).

I6 The two methods of the measurement of GDP used in this study are nominal (GDPn) and based on purchasing power parity (GDPp). GDPn is given in a simple conversion to the USD according to the conversion rate valid for the given year. It shows the strength of the economy of the given country (or group of countries) in international trade. In contrast, GDPp indicates the performance of the economy with respect to the price level in a given country (it is possible to purchase an entirely different amount of goods for instance in the USA and in Angola for USD I0o). The currency is 'current international dollar' (CID). This expression better reflects the real power of the economy of the given country over its own population.

I7 International Monetary Fund (2019); The Military Balance 2015 (2015), London: Routledge; Sipri Yearbook 20I6: Armaments, Disarmament and International Security (2016), Oxford: Oxford University Press; Globalfirepower (2019) '20I9 Military Strength Rating,' <https://www. globalfirepower.com/countries-listing.asp> (accessed on o8 September 2019).

I8 The division of countries regarding to their geopolitical power into several levels is one of the major topics of geopolitics. For one of the possible models, see • Cohen (2015), pp. 3-4.

I9 Huntington (1997), pp. I35-I36.

20 Huntington (1997), pp. 137-138.

2I Huntington (1997), pp. I39-I54.

22 It is almost impossible to get qualified estimations of GDP and population of Cuba and North Korea in I995-2020, esp. for the latter. See endnote 34.

23 he members of African civilizations are the following countries: Angola, Benin, Botswana, Burundi, Cameroon, Central African Republic, Chad, Democratic Republic of the Congo, Equatorial Guinea, Gabon, Ghana, Ivory Coast (Côte d'Ivoire), Lesotho, Liberia, Madagascar, Malawi, Mozambique, Namibia, Republic of Congo, Rwanda, São Tomé and Príncipe Islands, South Africa, South Sudan, Swaziland (Eswatini), Togo, Uganda, Zambia and Zimbabwe. These cleft countries also belong here: Kenya, Nigeria, 
Tanzania (all between the African and Islamic civilizations), Guyana and Suriname (both between the African and Hindu civilizations).

24 Bhutan, Cambodia, Laos, Mongolia, Myanmar (Burma), Sri Lanka and Thailand.

25 Hindu civilization comprises India and Nepal and further the cleft countries of Guyana and Suriname (both among the African and Hindu civilizations).

2/2020 26 It includes the Democratic People's Republic of Korea (DPRK, North Korea), People's Republic of China (PRC), Republic of China (Taiwan), Republic of Korea (South Korea), Vietnam and Singapore (the last being cleft between the Confucian and Islamic civilizations) as well as the autonomous regions of Macao and Hong Kong (both parts of the PRC).

27 The Latin American civilization consists of Argentina, Belize, Bolivia, Brazil, Chile, Colombia, Costa Rica, Cuba, Dominican Republic, Ecuador, El Salvador, Grenada, Guatemala, Honduras, Mexico, Nicaragua, Panama, Paraguay, Peru, Uruguay and Venezuela, as well as Puerto Rico (split between Western and Latin American civilizations).

28 Islamic civilization consists of Afghanistan, Albania, Algeria, Azerbaijan, Bahrain, Bangladesh, Brunei, Burkina Faso, the Comoros, Djibouti, Egypt, Eritrea, Gambia, Guinea, Guinea-Bissau, Indonesia, Iran, Iraq, Jordan, Kosovo, Kuwait, Kyrgyzstan, Lebanon, Libya, Malaysia, Maldives, Mali, Mauritania, Morocco, Niger, Oman, Pakistan, Qatar, Saudi Arabia, Senegal, Sierra Leone, Somalia, Sudan, Syria, Tajikistan, Tunisia, Turkey, Turkmenistan, the United Arab Emirates, Uzbekistan and Yemen. It also includes the cleft countries of Kenya, Nigeria, Tanzania (all between the African and Islamic civilizations), Bosnia and Herzegovina (between the Islamic and Orthodox civilizations), Singapore (between the Sinic and Islamic civilizations) and the Philippines (between the Islamic and Western civilizations).

29 The Orthodox civilization includes: Armenia, Belarus, Bulgaria, Cyprus, Georgia, Greece, Kazakhstan, Moldova, Montenegro, North Macedonia (Macedonia, FYR), Romania, Russia, Serbia, and two cleft countries, namely Bosnia and Herzegovina (between the Islamic and Orthodox civilizations) and Ukraine (between the Orthodox and Western civilizations).

30 Western civilization is comprised of Aruba, Australia, Austria, the Bahamas, Barbados, Belgium, Cabo Verde (Cape Verde), Canada, Croatia, Czech Republic, Denmark, East Timor (Timor-Leste), Estonia, Finland, France, Germany, Great Britain, Hungary, Iceland, Ireland, Israel, Italy, Latvia, Lithuania, Luxembourg, Malta, the Netherlands, New Zealand, Norway, Papua New Guinea, Poland, Portugal, Slovakia, Slovenia, the Solomon Islands, Spain, Sweden, Switzerland and USA. The cleft countries were the Philippines (between the Islamic and Western civilizations), Puerto Rico (between Western and Latin American civilizations) and Ukraine (between the Orthodox and Western civilizations).

3I This group includes: Antigua and Barbuda, Dominica, Ethiopia, Fiji, Haiti, Jamaica, Kiribati, Marshall Islands, Mauritius, Micronesia, Nauru, Palau, Saint Kitts and Nevis, Saint Lucia, Saint Vincent and the Grenadines, Samoa, Seychelles, Tonga, Trinidad and Tobago, Tuvalu and Vanuatu.

32 The following charts and analysis are my calculations based on the sources of International Monetary Fund and United Nations. However, for two countries, it was impossible to get qualified estimations for all the analyzed 
years. For Cuba and esp. North Korea (Democratic People's Republic of Korea), the exact data about development 1995-2020 are not available. Some estimations were done, they are however very contradictory to each other and always just for a couple of years. Therefore, I decided not to involve North Korea and Cuba into these statistics. Their estimated population and GDPp are for Cuba ca. II,I2 mil. people (20I8) and ca. I37 bn. ICD (20I7) and for North Korea ca. 25,38 mil. inhabitants (20I8) and ca. $40 \mathrm{bn}$. ICD (2015). Given that, the difference in statistics is clearly minimal. See CIA (2019) 'The World Factbook', <https:/www.cia.gov/ library/publications/the-world-factbook/geos/kn.html> (accessed on 28 July 20I9); Worldometers (2019) 'World population,' <https://www. worldometers.info/world-population $>$ (accessed on 28 July 20I9).

33 The abbreviations refer to the following civilizations: AFR = African, $\mathrm{BDH}$ $=$ Buddhist, $\mathrm{CNF}=$ Confucian $($ Sinic), $\mathrm{HIN}=$ Hindu, $\mathrm{ISL}=$ Islamic (Muslim), $\mathrm{JAP}=$ Japanese, LAT $=$ Latin-American, ORT $=$ Orthodox, WST $=$ Western .

34 The key role in the enormous growth of the African played two factors that can be judged largely positively in terms of civilizational progress: decreasing child mortality (as well as unnatural mortality overall) and reducing the number and intensity of armed conflicts. On the other hand, it is clear that this advancement simultaneously brought fundamental problems to the African continent, because it lacks sufficient resources for such large population growth (which affected for instance employment but also the mere production of foodstuffs). Should this phenomenon not be given enough attention, it could be a very dangerous development, esp. when we consider, that another big challenge for Africa is the expansion of uninhabitable areas (as a result of climate change).

35 The reduction of the population by more than one percent while the world population was growing at an unprecedented rate is not a good sign for the Orthodox Civilization, especially with regard to its large territorial area (and therefore very low average population density). In addition, especially in the case of the Russian Federation, the Muslim community has been growing very fast, thus compensating for the decline of the ethnically Russian population.

36 The huge fall in Japan's share of the economy over the past 25 years can to some degree be attributed to the economic policy of Prime Minister Abe (so-called Abenomics), characterized by a sharp rise in government debt and a loss of value for the currency. This thesis can be supported by the fact, that according to GDPp the Japanese economy has actually been growing. Nevertheless, this growth has been very slow and its share of world GDP has logically quickly and unambiguously decreased. At the same time, assuming its population, it is still the second most productive civilization after the Western. Japan's current position in the global economy seems to be more in line with its capabilities, while its almost I $8 \%$ of the GDPn at 2 $\%$ of the population in 1995 was a fluctuation reflecting the extraordinary successes of the Japanese economy during the Cold War. For analysis of Abenomics see David Chiavacci and Sébastien Lechevalier (eds.) (2018), Japanese Political Economy Revisited: Abenomics and Institutional Change, London: Routledge.

37 For example Carl J. Dahlman states, that „India has many strengths, particularly a young and growing population, experience and institutions of a market economy, a critical mass of entrepreneurs and highly skilled 
professionals, and a large public research infrastructure. It has the potential to leverage its strengths to improve its competitiveness and welfare.' At the same time however it „faces many internal challenges as well as a much more demanding and competitive international environment.' Carl J. Dahlman (2007), 'India's Knowledge Economy in the Global Context,' CEJISS in: Sujai J. Shivakumar and Charles W. Wessner (eds.) India's Changing 2/2020 Innovation System: Achievements, Challenges, and Opportunities for Cooperation: Report of a Symposium. National Academy Press, p. I6I, available at <https://www.nap.edu/read/II924/chapter/II\#I64> (accessed on o8 September 2019). Similarly, Saul Bernard Cohen concludes, that despite its strength, India "cannot currently be classed as a major power' for a variety of reasons - from its political fragmentation and corruption to poor industrial infrastructure. However, it has a "potential to correct these deficits,' which could „eventually raise India to the level of China as one of the great trading nations of the world.' Cohen (2015), p. 372.

38 Huntington proposed to allocate one permanent seat in the UN SC (associated with the right of veto) to each civilization, respectively its leading country. For Western civilization, he proposed two seats, for the US and the European Union. He himself was conscious of the significant shortcomings of his proposal - apart from EU issues, its biggest difficulty was identifying a leading state in some civilizations (see text below). He also did not foresee a seat for the Buddhist civilization. Huntington (I997), pp. 3I7-3I8.

39 Thailand is the strongest economy of the Buddhist civilization, but it is a question whether its position would not be threatened in a few decades by the growth of Myanmar (Burma).

40 Nigeria is the strongest economy and has the biggest population. On the other hand, it is a cleft country (between the African and Muslim civilizations). South Africa as an alternative leader, but its acceptance by other African countries can be a problem, because its economic dominance draws largely from its apartheid heritage.

4I Alternatively, Egypt could be a candidate because of its population and economic strength, but I have decided to leave it out.

42 Cohen (2015), p. 3.

43 It is obvious, that the parameters used below for categorizing countries into individual categories are entirely arbitrary.

44 The area is intended only for the land. Taking the sea surface into account would make the overview unnecessarily complicated.

45 This is, of course, a simplification, because the size of the territory and the population are different factors, but this simplification is applicable for the purposes of this study.

46 The reason is the elimination of extreme cases of countries where GDPn and GDPp would be diametrically different.

47 Proof of this is the very cautious US approach to the DPRK, whose geopolitical significance is otherwise substantially negligible. For the dilemmas about using nuclear weapons and problems of their deterrence power see e.g. Steve Fetter and Jon Wolfsthal (2018), 'No First Use and Credible Deterrence,' Journal for Peace and Nuclear Disarmament, Vol. I, No. I, pp. I02-II4, DOI: I0.Io8o/2575I654.20I8.I454257, available at <https:// www.tandfonline.com/doi/full/Io.Io80/2575I654.20I8.I454257> (accessed on o8 September 2019) 
48 The analysis of conventional military power is based on quantitative criteria. Of course, the quality of military power is an entirely different issue. For example, the Abrams tank is barely comparable to WWII-era Shermans (still in stores of several countries) and the T-9o tank is far more modern than the T-55, whose roots date back to late I940s. North Korea's army, although ca three times bigger than the of South Korea, is assessed as „qualitatively inferior to South Korea's modern forces'. See The Military Balance (2015), p. 226. Many more such examples could be found. Therefore, the Globalfirepower Index has been included, because it values qualitative criteria as well. It is measured by Globalfirepower.com. It is based on an analysis of 55 factors influencing the military strength of a country. The lower the index, the higher the combat capability - the ideal index would be o. See Globalfirepower (20I9). As with the IMF data, it is not important to what extent this analytical tool is accurate, but rather to the fact that it is created by a consistent methodology and can therefore serve as a relevant source for comparison.

49 Military personnel include active military manpower (incl. paramilitary) plus reserves (without paramilitary).

50 Anti-submarine warfare and attack aircrafts and helicopters, fighter and fighter ground attack aircrafts, bombers and multi-role helicopters.

5I Main battle tanks, light tanks, armored infantry fighting vehicles, armored personnel carriers and ambitious assault vehicles (all incl. stored reserves).

52 Aircraft carriers, nuclear-powered ballistic missile submarines and submarines with nuclear ballistic missiles. The aircraft carrier is to a large extent a matter of prestige, but on the other hand, it undoubtedly allows the shift of combat area to the territory of almost the whole world. For the aircraft carrier, only fully-fledged aircraft carriers are counted i.e. not e.g. Japanese helicopter ships. See The Military Balance (2015). For submarines, the review is limited to only the most serious categories, i.e. submarines capable of a large nuclear strike.

53 The country must fulfill the criteria of power of at least two indicators of conventional military power to be included in table 7 .

54 For USA, only the 50 states + DC are counted, i.e. overseas territories are omitted. For the North Korea, the statistics of CIA (2019), Worldometers (2019) and The Military Balance (2015) were used.

55 Legend: $\mathrm{ARG}=$ Argentina, $\mathrm{AUS}=$ Australia, $\mathrm{BRA}=$ Brazil, $\mathrm{CAN}=\mathrm{Canada}$, DPRK = North Korea, EGY = Egypt, FRA = France, GER = Germany, IDN = Indonesia, IND = India, IRN = Iran, ISR = Israel, ITA = Italy, JPN = Japan, MEX $=$ Mexico, NIG $=$ Nigeria, PAK $=$ Pakistan, PRC $=$ People's Republic of China, ROC $=$ Republic of China (Taiwan), ROK $=$ South Korea, RUS $=$ Russia, RSA = South Africa, SAU = Saudi Arabia, THA = Thailand, TUR = Turkey; UK $=$ United Kingdom, USA = United States of America, VNM = Vietnam; AR = share of world's land mass, POP = share of world's population, GDPn = share of world's GDPn, GDPp = share of world's GDPp, NW = number of nuclear warheads (including reserve and decommissioned), $\mathrm{MP}=$ military personnel (thousands of persons), $\mathrm{CA}=$ number of combat aircraft, $\mathrm{ACV}$ = number of armored combat vehicles; ACS number of aircraft carriers + submarines with ballistic nuclear missiles, GFPI = Global Firepower Index.

56 Democratic People's Republic of Korea has conducted several nuclear tests since 2006 and undoubtedly possesses nuclear weapons. On the other hand, it is believed, that it doesn't have nuclear warheads small and light 
enough to be delivered through missile or aircraft (however, it is only the matter of time).

57 It is clear that for the PRC the achievement of a comprehensive status of a superpower (the expansion of nuclear arsenal) would have been much easier. Russia, on the other hand, has virtually no chance of quintupling CEJISS its share of the global economy, as its economy faces protracted structural $2 / 2020$ problems (dependence on the export of raw materials), and dozens of years of planned reform are still largely not in sight. Indeed, the table also shows, that while the PRC is in the category of a power for its nuclear arsenal, Russia is not in that category because of its economy.

58 Like in the case of China, India can assume (if maintaining the current trends) the achievement of full superpower status in approximately one to two decades. According to estimates of International Monetary Fund, India's share of world GDPn between 2015 and 2020 would rise from $2.82 \%$ to $3.53 \%$ and the one of GDPp from $6.94 \%$ to $8.38 \%$. Even if this pace is to slow, it can be assumed that around 2030 it will reach about $15 \%$ in GDPp and about $8 \%$ in GDPn. Such a strong economy would undoubtedly (like the Chinese) manage to increase its nuclear arsenal in a relatively short period of time, if necessary. International Monetary Fund (2019).

59 All the countries matching at least 4 of the 5 parameters of conventional military power are included into powers (see above).

6o However, when using GDP per capita, it can never be forgotten that it does not reflect the real wealth of the population. It is merely a mathematical operation. However, the aim of this study is not to address the welfare of the population, but the power of individual civilizations, which is why this parameter can be used - of course, with full awareness of the above.

6I For the African civilization (33 members), the 7 (= rounded $20 \%$ ) richest and poorest countries are taken into account. For the other civilizations, the numbers are following: Buddhist I, Hindu I, Sinic 2, Latin-American 4, Islamic Io, Orthodox 3, Western 9.

62 The average GDP was calculated by the simple arithmetic average of the GDP of the countries surveyed. It did not take into account the population of the given country. The reason was the same as in the endnote 62 - it is a comparison of countries rather than the average welfare of the population.

63 Of course, Japanese civilization is specific. Because it is made up of a single country, it automatically has full compactness according to this methodology. Using e.g. the Gini Index Japan ranked in 2011 to countries with medium inequalities (its Gini index was 37.9, the average of the 156 countries surveyed was 39.0 and the median 37.9). However, this study focuses on differences between states, so the Japanese civilization is ranked among the compact. See CIA (2019).

64 In this case as well, the criteria were arbitrarily determined by the author.

65 Uppsala Conflict Data Program (2019) 'UCDP/PRIO Armed Conflict Dataset version I9.I.,' <https://ucdp.uu.se/downloads/\#d3> (accessed on o6 September 2019). For an inspiring analysis of similar databases and their use, see Lenka Kursová (2017), Možnosti výzkumu aktérů ozbrojených konfliktů [The possibilities of research of the actors of armed conflicts], Diplomová práce Západočeské univerzity v Plzni [Thesis for the University of West Bohemia in Pilsen].

66 Uppsala Conflict Data Program (2019). 
67 Legend: CFL = Conflict; CNW = Cenepa War, January-February I995), BKC = Bakassi Border Conflict, May I996, ICW = First Congo War, I996-I997, $2 \mathrm{CW}=$ Second Congo War, I998-2003, CCW = Republic of the Congo Civil War, I997-I999, SLW = Civil War in Sierra Leone, I99I-2002, DEC = Djiboutian-Eritrean Border Conflict, June 2008, RGW = Russo-Georgian War, August 2008, CTD = Cambodian-Thai Border Dispute, 2008-200I, $\mathrm{M} 23$ = M23 Rebellion, 2012-2013, WDB = War in Donbass, 2014-present, YCW = Yemeni Civil War, 2015-present); Year = calendar year in which

S. P. Huntington's Civilizations there were at least 25 direct victims (thus, it may not have covered all the years of the conflict, and on the contrary, the conflict may have lasted even a single day); Side A/B - two sides of the fighting, included only states, respectively their official governments. The countries marked in cursive were sending military support to direct participants; Type $2=$ inter-state conflict, type 4 = internationalized internal conflict; INT = intensity of the conflict; I = low intensity (25-999 direct victims), 2 = high intensity (I,000 or more direct victims). $\mathrm{CIV}=$ civilization, abbreviations of the civilizations, see the endnote 35; Coalition (supporting the rebels) = Bahrain, Egypt, Jordan, Morocco, Qatar, Saudi Arabia, Sudan, United Arab Emirates.

68 The criteria were again arbitrarily determined by the author. 